\title{
Onverwerkte pyn word onnodige bagasie vir die volgende generasie
}

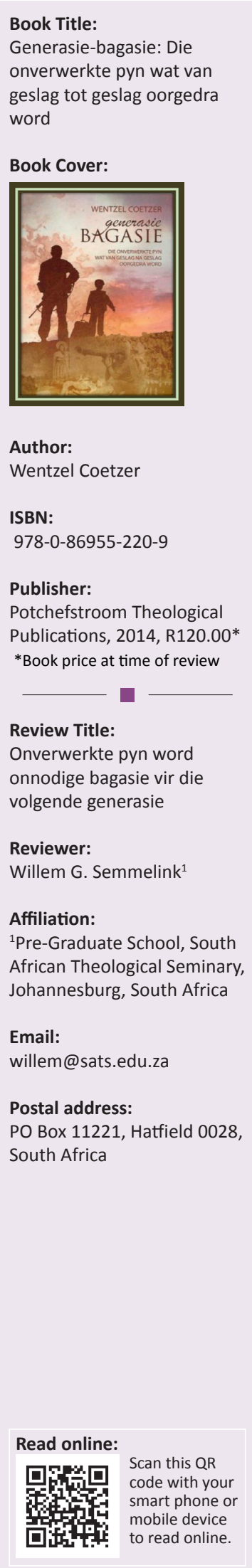

Book Title:

onverwer

geslag tot geslag oorgedra

\section{Book Cover:}

Author:

ISBN:

978-0-86955-220-9

Potchefstroom Theological

Review Title:

Onverwerkte pyn word

onnodige bagasie vir die

gende generasie

Reviewer:

Willem G. Semmelink

Affiliation:

Johannesburg, South Africa

Email:

willem@sats.edu.za

PO Box 11221, Hatfield 0028,
Generasie-bagasie bied 'n oorsig oor die idee en werklikheid dat mense wat as gevolg van hulle eie verlede, of die invloed wat ander mense se verlede op hulle gehad het, nou ander mense se lewe beïnvloed. Deur voorbeelde uit die werke van Murray Bowen en Kenneth McAll word lesers gehelp om die teorie en die praktyk bymekaar te bring. Die boek wys op maniere waarop persone met soortgelyke probleme gehelp kan word om die verlede en die invloed daarvan op die persoon, asook die invloed wat dit op die interpersoonlike verhoudings het, te openbaar en te hanteer met duidelike afgebakende grense. Die gebruik van bepaalde rituele soos die nagmaal versterk die rol wat geestelike groei in die genesing van die individu asook in die familie, vriende en gemeenskap kan speel.

Die invloed wat traumatiese ervarings op die individu en interpersoonlike verhoudings in die familie en die gemeenskap het, is relevant in die Suid-Afrikaanse gemeenskap. Hierdie gemeenskap word nog steeds deur die effek wat die grensoorlog in die vorige dekades gehad het, geraak asook die toename van misdaad wat tans ons land teister. Dit is noodsaaklik dat mense wat berading doen goeie begrip en kennis moet hê hoe om mense deur die effek wat die verlede op hulle het, te begelei. Die regte stappe moet geneem word om genesing, vergifnis, die herstel van verhoudings en veral ook hulle verhouding met God te bewerkstellig.

Hierdie boek is vir alle mense bedoel wat by berading of gesinsbediening betrokke is. Selfs onderwysers kan baat vind daarby om 'n beter begrip vir die kinders se omstandighede en hulle gedrag te verkry. Kinders se gedrag word dikwels deur omstandighede oorgedra en dit is soms 'n kringloop wat al deur geslagte heen so voortduur. Die nodige kennis word in eenvoudige taal en met voorbeelde op so ' $n$ wyse oorgedra dat die lesers 'n goeie begrip vir die sielkundige, sosiale, liggaamlike en geestelike invloed verkry wat die bagasie van generasies op 'n mens kan hê.

Dit is 'n eenvoudige en praktiese boek oor 'n belangrike aspek wat mense oor geslagte heen kon beïnvloed het. Hierdie besondere boek poog om mense met hul generasie se bagasie te help!

How to cite this book review: Semmelink, W.G., 2015, 'Onverwerkte pyn word onnodige bagasie vir die volgende generasie', In die Skriflig 49(1), Art. \#1954, 1 page. http://dx.doi.org/10.4102/ids.v49i1.1954

Copyright: @ 2015. The Authors. Licensee: AOSIS OpenJournals. This work is licensed under the Creative Commons Attribution License. 